\title{
Hepatitis C Virus Seroconversion Among Hemodialysis Patients and the Role of Hepatitis C Virus Positive Patient's Isolation in Benha, Egypt
}

\author{
Mohamed El-Tantawy Ibrahim ${ }^{1}$, Mona Ahmed Elawady ${ }^{2}$ \\ ${ }^{1}$ Internal Medicine Department, Faculty of Medicine, Benha University, Benha, Egypt \\ ${ }^{2}$ Public Health Department, Faculty of Medicine, Benha University, Benha, Egypt \\ Email address: \\ Tantawy_d@yahoo.com (M. El-Tantawy I.),Dr_monaelawady@yahoo.com (M. A. Elawady)
}

\section{To cite this article:}

Mohamed El-Tantawy Ibrahim, Mona Ahmed Elawady. Hepatitis C Virus Seroconversion Among Hemodialysis Patients and the Role of Hepatitis C Virus Positive Patient's Isolation in Benha, Egypt. Clinical Medicine Research. Vol. 6, No. 2, 2017, pp. 31-36. doi: 10.11648/j.cmr.20170602.11

Received: January 7, 2017; Accepted: February 6, 2017; Published: March 2, 2017

\begin{abstract}
The prevalence of hepatitis C virus (HCV) infection in hemodialysis units (HD) is higher than among normal population. Seroconversion was included in many previous studies which constitute a great problem against infection control policies. The aim of this study was to evaluate seroconversion rate and the effect of isolation of hepatitis $\mathrm{C}$ positive patients as infection control method. This is controlled prospective study that included 90 patients for 2 years. Isolation policy of hepatitis $\mathrm{C}$ positive patients was implemented in the second year of the study. The prevalence of HCV was $48.9 \%$ among hemodialysis patients. Seroconversion rate decreased from $15.2 \%$ in the first year to $5.1 \%$ in the second year after application of isolation. The duration of hemodialysis in months, positive history of blood transfusion and the amount of transfused blood were considered significant factors affecting seroconversion. so we concluded that Isolation of hepatitis $\mathrm{C}$ positive patients as an infection control policy is mandatory to control HCV seroconversion in Egypt.
\end{abstract}

Keywords: HCV, Isolation, Seroconversion and HD

\section{Introduction}

End stage renal disease (ESRD) has become a public Health problem worldwide as the total number of patients was increasing duo to the increased prevalence of hypertension and diabetes mellitus [1]. Also ESRD patients are requiring different modality of renal replacement therapy (RRT), which put more burdens on health budget especially in devolving countries [2].

Egypt has the largest burden of HCV infection worldwide which is the most common chronic blood-borne infection ${ }^{[3,}$ 4]. The at risk groups include patients that receive multiple blood transfusions as hemophiliacs, individuals who are intravenous and inhalant drug users and hemodialysis patients [5].

The prevalence of $\mathrm{HCV}$ infection among HD patients is generally much higher than general population due to underlying impaired cellular immunity which increases their susceptibility to infection. Also HD requires prolonged vascular access and exposure to contaminated equipment. In addition HD patients required blood transfusion, frequent hospitalization and surgery, which increase opportunities forgetting nosocomial infection exposure [6]. HD staff was found also to be an important factor in transmission of $\mathrm{HCV}$ infections among HD patients [7].

The prevalence of $\mathrm{HCV}$ infection among HD patients in developed countries ranges from 3.6 to $20 \%$ and is higher in the developing countries [8] and in Egypt, it ranges from $49 \%$ to $64 \%$ [9].

$\mathrm{HCV}$ is responsible for over one million patient's deaths from cirrhosis and liver cancer every year [4]. It has been associated with high morbidity and mortality rates and the management of these infections among HD patients with specific antiviral agents is associated with high rates of adverse effect [10].

Isolation of $\mathrm{HCV}$ positive patients in $\mathrm{HD}$ units is recommended by many authors [11, 12].

The rational of this study was to declare that isolation of hepatitis $\mathrm{C}$ positive patients as an infection control policy is mandatory to control HCV seroconversion in Egypt. 


\section{Patients and Methods}

This controlled prospective study was conducted at HD unit, Benha university hospital from October 2014 to October 2016. We included all the patients who were on HD and at the end of the study and exclude all patients who transferred from our unit, died before the end of the study or received any HD sessions outside our unit. Also we did not include new HD patient who started HD after the study had been started. Final number of the study was 90 patients.

The aim of this study was to evaluate seroconversion rate and the effect of isolation of hepatitis $\mathrm{C}$ positive patients as infection control method.

All new patients who will start HD sessions must do virology testing for Human immunodeficiency virus (HIV), hepatitis B virus (HBV) and HCV, and it must be repeated every 3 months. But we don't accept HBV or HIV positive patients.

For all patients, complete history was taken including age, gender, duration of $\mathrm{HD}$, any surgical procedure, family history of $\mathrm{HCV}$ infection, vascular access and history of blood transfusion.

For HCV diagnosis we used third generation enzymelinked immunosorbant Assay (ELISA) for detection of HCV antibodies (AB). Follow up of patients was carried out without isolation in the first year; then we applied isolation policy of HCV positive patients in October 2015, and follow up the patients continued for another year.

Annual serocnversion (any patient who was $\mathrm{HCV} \mathrm{AB}$ negative and became $\mathrm{HCV} \mathrm{AB}$ positive ) rate was calculated as number of $\mathrm{HCV}$ positive seroconverted patients in one year subdivided by number of $\mathrm{HCV}$ negative patient and multiply by 100 .

\section{Statistical Analysis}

The collected data were summarized in terms of mean \pm SD for quantitative data and frequency and percentage for categorical data. The test of proportion (Z-test), chi square test and fisher exact test were used to compare categorical variables while student $t$ test was used to compare quantitative variables. A P-value $<0.05$ was considered statistically significant. All statistical analysis was carried out using the computerized Statistical Package for Social Science (SPSS; Version 20.0 for Windows, SPSS Inc., Chicago, IL).

\section{Results}

This study included 90 patients on regular HD in Benha University Hospital, Egypt (56.7\% were male and $43.3 \%$ were female). They had a mean age of 54.41 years (standard deviation 10.81). The prevalence of HCV infection was $48.9 \%$ (44 patients). Among the negative group for HCV infection (46 patients) who started HD, 9 patients seroconverted at the end of the study. Participants had been on dialysis for a mean duration of 44.39 months (standard deviation 18.1). About one third of them had positive history of blood transfusion (more than $50 \%$ of them get $\geq 3$ units (Table 1).

Table 1. Characteristics of patients.

\begin{tabular}{ll}
\hline & Value \\
\hline Age in years & \\
\hline Mean \pm SD (range) & $54.41 \pm 10.81(21-76)$ \\
Sex n (\%) & \\
Male & $51(56.7)$ \\
Female & $39(43.3)$ \\
HCV n (\%) & \\
Positive & $44(48.9)$ \\
Negative & $46(51.1)$ \\
Vascular access & \\
AVF & $63(70.0)$ \\
Catheter & $27(30.0)$ \\
Duration of HD in months & \\
Mean \pm SD (range) & $44.39 \pm 18.1(12-120)$ \\
Blood transfusion $n$ (\%) & \\
Yes & $30(33.3)$ \\
No & $60(66.7)$ \\
Amount of blood transfusion (32) & \\
$<3$ units & $14(46.7)$ \\
$\geq 3$ units & $16(53.3)$ \\
Conversion from negative HCVAB to positive & \\
Yes & $9 / 46$ \\
No & $37 / 46$ \\
\hline
\end{tabular}

Table 2 showed that there were no significant difference between cohorts with $\mathrm{HCV}$ infection versus cohorts without it regarding age, sex and vascular access $(\mathrm{p}>0.05)$.

Table 2. Comparison between HCV positive and negative patients.

\begin{tabular}{lllll}
\hline & Positive HCV (44) & Negative HCV (46) & test & P* \\
\hline Age in years & $53.07 \pm 10.95$ & $55.70 \pm 10.62$ & \multirow{2}{*}{0.25} \\
Mean \pm SD (range) & $(21-76)$ & $(30-71)$ & & \\
Sex n (\%) & & & $\$ 0.01$ & \\
Male & $25(56.8)$ & $26(56.5)$ & & \\
Female & $19(43.2)$ & $20(43.5)$ & & \\
Vascular access & & & $\$ 0.01$ \\
AVF & $31(70.5)$ & $32(69.6)$ & & 0.93 \\
Catheter & $13(29.5)$ & $14(30.4)$ & & \\
\hline
\end{tabular}

\#= student $\mathrm{t}$ test $\$=$ chi square test

The cohort was divided into two groups: Group I consisted of 9 patients $(66.7 \%$ male and $33.3 \%$ female $)$ who were negative for $\mathrm{HCV}$ when they started $\mathrm{HD}$ and seroconverted during HD to $\mathrm{HCV}$ positive and group II consisted of 37 patients ( $54.1 \%$ male and $45.9 \%$ female) who were negative for $\mathrm{HCV}$ when they started $\mathrm{HD}$ and remained negative. 
Comparison between the studied groups with regard to the risk factors for HCV seroconversion showed that the duration of HD in months $(67.11 \pm 12.26$ in group I and $40.73 \pm 17.29$ in group II) and a positive history for blood transfusion and amount of transfused blood were the significant factors between the two studied groups.

A positive family history of HCV infections and surgical operation history were non-significant among the studied groups (Table 3).

Table 3. Seroconversion to HCV seropositive patients among HCV seronegative patients.

\begin{tabular}{|c|c|c|c|c|}
\hline & Group I Positive seroconversion (9) & Group II Negative seroconversion (37) & Test & $\mathbf{P}^{*}$ \\
\hline $\begin{array}{l}\text { Age in years } \\
\text { Mean } \pm \mathrm{SD} \text { (range) }\end{array}$ & $\begin{array}{l}51.89 \pm 10.86 \\
(30-67)\end{array}$ & $\begin{array}{l}56.62 \pm 10.51 \\
(30-71)\end{array}$ & $\# 1.20$ & 0.24 \\
\hline \multicolumn{5}{|l|}{ Sex n $(\%)$} \\
\hline Male & $6(66.7)$ & $20(54.1)$ & $\wedge 0.10$ & 0.76 \\
\hline Female & $3(33.3)$ & $17(45.9)$ & & \\
\hline $\begin{array}{l}\text { Duration of HD in months } \\
\text { Mean } \pm \text { SD (range) }\end{array}$ & $\begin{array}{l}67.11 \pm 12.26 \\
(49-90)\end{array}$ & $\begin{array}{l}40.73 \pm 17.29 \\
(12-90)\end{array}$ & \#4.31 & $0.001 * *$ \\
\hline \multicolumn{5}{|l|}{ Blood transfusion n (\%) } \\
\hline Yes & $6(66.7)$ & $29(78.4)$ & $\wedge 4.97$ & $0.03 *$ \\
\hline No & $3(33.3)$ & $8(21.6)$ & & \\
\hline \multicolumn{5}{|l|}{ Amount of blood transfusion } \\
\hline$<3$ units & $1(16.7)$ & $7(87.5)$ & $\wedge 4.43$ & $0.04 *$ \\
\hline$\geq 3$ units & $5(83.3)$ & $1(12.5)$ & & \\
\hline \multicolumn{5}{|l|}{ Surgery n (\%) } \\
\hline Yes & $8(88.9)$ & $22(59.5)$ & $\wedge 1.62$ & 0.13 \\
\hline No & $1(11.1)$ & $15(40.5)$ & & \\
\hline \multicolumn{5}{|l|}{ Family history } \\
\hline Yes & $7(77.8)$ & $23(62.2)$ & $\$ 0.78$ & 0.38 \\
\hline No & $2(22.2)$ & $14(37.8)$ & & \\
\hline After one year (before isolation) & $7 / 46(15.2)$ & $39(84.8)$ & $£ 6.57$ & $0.001 * *$ \\
\hline After 2 years (after isolation) & $2 / 39(5.1)$ & $37(94.9)$ & $£ 12.70$ & $0.001 * *$ \\
\hline
\end{tabular}

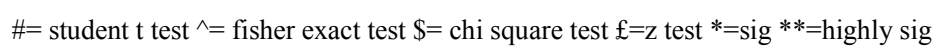

After one year (before isolation) $15.2 \%$ of the negative group for $\mathrm{HCV}$ infection had converted while only $5.1 \%$ converted in the second year of the study (after isolation) which was statistically significant $(\mathrm{p}=0.02)$ (Table 4).

Table 4. Seroconversion before and after isolation.

\begin{tabular}{lllll}
\hline & $\begin{array}{l}\text { Before } \\
\text { isolation (46) }\end{array}$ & $\begin{array}{l}\text { After isolation } \\
(\mathbf{3 9})\end{array}$ & $\mathbf{Z}$ test & P* \\
\hline Positive conversion & $7(15.2)$ & $2(5.1)$ & 2.0 & $0.02 *$ \\
Negative conversion & $39(84.8)$ & $37(94.9)$ & 0.23 & 0.41 \\
\hline
\end{tabular}

\section{Discussion}

Contaminated blood products and needles and instruments were considered as major sources for transmission of $\mathrm{HCV}$ [13]. Also, inadequate application and or breakdown of infection control policies in HD units (contamination of dialysis machines and, improper decontamination and sterilization, inadequately trained staff and unawareness of the value of hand washing) increase the transmission of $\mathrm{HCV}$ [14].

Several studies have reported nosocomial patient to patient transmission of HCV infection among HD patients $[15,16]$.

This study evaluated the incidence of seroconversion of HCV among HD patients in Benha university hospital HD unit, and the effect of isolation of $\mathrm{HCV}$ positive patients on HCV seroconversion.

Isolation included dedicated HD machines, personnel, area and other barrier precautions (aprons, gowns, or gloves), used by healthcare professionals take care of $\mathrm{HCV}$ positive patients.

As regard general Characteristics of this study, it was found that the mean age of starting HD was 54.41 years. This was in agreement with some Egyptian studies [17, 18, and 19]. The increasing mean age of HD starting reflects the improvement of health care; but, we are still away from developed countries as the mean age in the United State was 61.1 years [20] and the median age in the United Kingdom was 65.9 years [21], but we are better than other developing countries as in Sudan (45.78 years) [22].

According to the gender, more than half of patients was male (56.7). This was in accordance with previous Egyptian studies $[18,19]$ which found that male constituted $53.7 \%$ and $61.0 \%$ respectively. Also in United States the male patients were more than female patients on HD as males represented about $55.0 \%$ to $61.0 \%$ according to different areas in United States [23].

In our study patients used only 2 types of vascular access, arterio-venous fistula (AVF) and temporary catheter. According to National Kidney Foundation, AVF is the best choice for HD, followed by arteio- venous graft and lastly catheter [24]. In this study there were $63 \%$ of patients uses AVF and $27.0 \%$ uses catheters.

In the present study, the prevalence of HCV among HD patients was $48.9 \%$ which was higher than Al Gharbiyah governorate, Egypt (35.0\%) [19], Kafer El-Shakh governorate, Egypt (39.7\%) [25] and much higher than in developed countries (3.6 to 20.0\%) [8] and Morocco (32.0\%) [26]. High prevalence of HCV among HD patients in Egypt is coinciding with that Egypt has the largest epidemic for 
hepatitis C virus Worldwide [27].

As a comparison between $\mathrm{HCV}$ positive and $\mathrm{HCV}$ negative patients, we found that the mean age of $\mathrm{HCV}$ positive patients (53.07 years) was lower than $\mathrm{HCV}$ negative patients (55.7 years). The same result was reported in Libya [28]. But in Saudi Arabia they found that HCV is more common among the elderly as the immunity decreased with aging [29].

In our study the number of males was more than females in both $\mathrm{HCV}$ positive patients $(56.8 \%)$ and $\mathrm{HCV}$ negative patients (56.6\%). This was in agreement with Ayman, 2007 who added that Most of the studies did not find any effect of the sex on the incidence or prevalence of HCV infection [30].

The Dialysis Outcome and Practice Pattern Study (DOPPS) showed that high HCV seroconversion was associated with a longer duration on dialysis, and seroconversion was associated with an increase in the HCV prevalence, but not with the isolation of $\mathrm{HCV}$-infected patients [31].

In our study there were $46 / 90 \mathrm{HCV}$ negative patients at the start and at the end of the study after two years $9 / 46$ patients had been seroconverted to be $\mathrm{HCV}$ positive with seroconvertion rate $15.2 \%$ in first year and $5.1 \%$ in second year.

As regard comparison between seoconverted $\mathrm{HCV}$ patients (group I) and none seroconverted HCV patients (group II), we found that mean age of group I was insignificantly lower than mean age of group II. This wasn't in agreement with another study done in Egypt as they found the mean age in seroconverted $\mathrm{HCV}$ patient was higher than nonseroconverted patient [32]. This can be explained as in our study that the mean age of $\mathrm{HCV}$ positive patients was lower than $\mathrm{HCV}$ negative patients.

In this study males were more than females in seoconverted HCV patients. This was in accordance with another study in Egypt in which males were more in seroconverted and females were more in non-seroconverted [18].

According to duration of HD in months, group I had significantly longer duration than group $2(p<0.001)$. And this was in agreement with Soliman etal., who added that the duration on regular HD was found to be a significant predictor for HCV seroconversion in HD patients [32]. Also in another study done in Menoufia governorate, Egypt, they found that long duration of HD led to more exposure in HD units, with increased risk of HCV nosocomial infection [18].

The history of blood transfusion and total number of units (more than 3 units) were significant risk factors for $\mathrm{HCV}$ seroconversion in this study. Blood transfusion was still a significant relative risk for $\mathrm{HCV}$ seroconversion in $\mathrm{HD}$ patients [32] even after the introduction of nucleic acid amplification testing for the screening of blood donors which has markedly reduced the risk of HCV transmission through blood product transfusion [33]. But another study reported that blood transfusion had no significance as a risk factor in HCV seroconvertion [18].

In this study the surgical history was more insignificantly in group 1 than group 2. This also was reported in another study as it found that surgical history had no significance as a risk factor in HCV seroconvertion [18].
As regard family history, positive family history was more common in the seroconverted HCV patients; but this was not significant. This wasn't in agreement with another study that found that positive family history of $\mathrm{HCV}$ infection was significant risk factor for $\mathrm{HCV}$ seroconversion in $\mathrm{HD}$ patients [18].

HCV seroconvertion rate $(15.2 \%)$ in first year (no isolation) was compared with a study done at $\mathrm{Al}$ Gharbiyah governorate, Egypt where HCV seroconversion rate was $11 \%$ [19] but the prevalence of HCV-Ab was $35 \%$ in all $\mathrm{HD}$ patients in comparison with our study which was $48.9 \%$.

Improving Global Outcome (KDIGO guidelines) didn't recommend the isolation policy for $\mathrm{HCV}$-infected patients and did not even recommend the use of dedicated machines for them [34]. But in 2 studies in Saudi Arabia and Spain, they concluded that complete isolation of $\mathrm{HCV}$-negative and $\mathrm{HCV}$-positive patients and machines with strict adherence to infection control policies and procedures, can even eliminate nosocomial transmission and obtain reduction in prevalence and seroconvesion of $\mathrm{HCV}[35,36]$.

Finally, HCV seroconversion in first year (before isolation) was $15.2 \%$ (7 patients from $46 \mathrm{HCV}$ negative patients) and decreased to $5.1 \%$ (2 patients from $39 \mathrm{HCV}$ negative patients), and this decrease was statistically significant $(\mathrm{p}<0.02)$. This was agreed by Egyptian study compare between centers uses isolation of HCV positive patients and others don't, and found that seroconversion seen only in units not use isolation [17]. Other studied in Egypt in three different governorates found that incidence of HCV seroconversion is significantly lower in the group of patients within units implementing isolation programs of the HCV infected patients [32]. Also studies done in Saudi Arabia and Spain supported our finding and added that, strict isolation is mandatory in HD units [35, 36]. But in another study done in Peru, they did not found differences in terms of the number of participants developing $\mathrm{HCV}$ infection when comparing the use of dedicated HD machines for $\mathrm{HCV}$ infected patients with the use of nondedicated machines [11].

\section{Conclusion}

In areas with high prevalence of HCV like Egypt, the prevalence of HCV in HD patients is high. So application of infection control policies and procedures which including isolation of $\mathrm{HCV}$ positive patients helps in decreasing $\mathrm{HCV}$ seroconversion.

\section{References}

[1] Perico N, Cattaneo D, Bikbov B and Remuzzi G: Hepatitis C infection and chronic renal diseases. Clin J Am SocNephrol. 2009;4 (1): 207-20.

[2] Bello AK, Nwankwo E and El Nahas AM: Prevention of chronic kidney disease: a global challenge. Kidney Int 2005; 98: 11-17. 
[3] Paez Jimenez A, Mohamed MK, SharafEldin N, AbouSeif H, El Aidi S, Sultan Y, Elsaid N, Rekacewicz C, El-Hoseiny M, El-Daly M, Abdel-Hamid M and Fontanet A: Injection drug use is a risk factor for HCV infection in urban Egypt. PloS One. 2009; 4: e7193.

[4] Hahn JA: Sex, drugs and hepatitis C Virus. J Infect Dis. 2007 Jun 1; 195 (11): 1556-9.

[5] Galperim B, Mattos AA, Stein AT, Schneider NC, Buriol A, Fonseca A, Lunge V and Ikuta N: Hepatitis C in hemodialysis: the contribution of injection drug use. The Brazilian Journal of Infectious Diseases. 2010; 14 (4): 422-6.

[6] Khan S, Attaullah S, Ali I,Ayaz S, Naseemullah, Khan SN, Siraj $\mathrm{S}$ and Khan J: Rising burden of Hepatitis C Virus in hemodialysis patients. J Virol. 2011; 8: 438.

[7] Fabrizi F., Messa P. and Martin P.: Transmission of hepatitis C virus infection in hemodialysis: current concepts. Int $\mathrm{J}$ Artif Organs. 2008; 31 (12): 1004-16.

[8] Afifi A.: The Egyptian Renal Registry. The 9th annual report for the year 2008 Published on 29th Annual congress of nephrology of Egyptian Society of Nephrology and Transplantation ESNT Hurghada Egypt 2009.

[9] Egyptian Renal Registry: 2008 report, ESNT congress, Hurghada Egypt, February, 2009.

[10] Jadoul M, Poignet JL, Geddes C, Locatelli F, Medin C, Krajewska M, Barril G, Scheuermann E, Sonkodi S and Goubau P; HCV Collaborative Group: The changing epidemiology of hepatitis $\mathrm{C}$ virus (HCV) infection in hemodialysis, European multicentre study. Nephrol Dial Transplant. 2004; 19 (4): 904-9.

[11] Bravo Zuñiga JI, LozaMunárriz $\mathrm{C}$ and López-Alcalde J: Isolation as a strategy for controlling the transmission of hepatitis $\mathrm{C}$ virus (HCV) infection in haemodialysis units. Cochrane Database of Systematic Reviews 2016, 8. Art. No.: CD006420.

[12] Delarocque-Astagneau E, Baffoy N, Thiers V, Simon N, de Valk H, Laperche S, Couroucé AM, Astagneau P, Buisson C, Desenclos JC.: Outbreak of hepatitis $\mathrm{C}$ virus infection in a hemodialysis unit: potential transmission by the hemodialysis machine? Infec Control HospEpidemiol2002; 23 (6): 328-34.

[13] Al-Jiffri AM, Fadeg RB, Ghabrah TM and Ibrahim A.: Hepatitis $C$ virus infection among patients on hemodialysis in Jeddah: A single center experience. Saudi J Kidney Dis Transplant. 2003; 14 (1): 84-9.

[14] Goldberg D and Anderson E.: Hepatitis C: Who is at risk and how do we identify them? J Viral Hepatitis. 2004; 11 (1): 12-8.

[15] Iwasaki Y, EsumiM, HosokawaN, YanaiM, and KawanoK: Occasional infection of hepatitis $\mathrm{C}$ virus occurring in hemodialysis units identified by serial monitoring of the virus infection, Journal of Hospital Infection, 2000; 45 (1): 54-61.

[16] Schneeberger PM, Keur I, Van Loon AM, Mortier D, De Coul KO, Van Haperen AV, Sanna R, Van Der Heijden TG, Van Den Hoven H, Van Hamersvelt HW, Quint W and Van Doorn $\mathrm{LJ}$ : The prevalence and incidence of hepatitis $\mathrm{C}$ virus infections among dialysis patients in the Netherlands: a nationwide prospective study," Journal of Infectious Diseases, 2000; 182 (5): 1291-9.

[17] Nasser ME, Younes KM, Sany DH, Youssef SS, Mahmoud M and El-Sayed BS: HCV Seroconversion in two Egyptian
Hemodialysis Units: Role of Detection Method and Patients Isolation, Macedonian Journal of Medical Sciences, 2014; 2 (1): 124-127.

[18] Zahran AM: Prevalence of seroconversion of hepatitis C virus among hemodialysis patients in Menoufia Governorate, Egypt.Arab J Nephrol Transplant 2014, 7 (2): 133-5.

[19] Khodir SA, Alghateb M, Okasha KM and Shalaby SS: Prevalence of HCV Infections Among Hemodialysis Patients in Al Gharbiyah Governorate, Egypt, Arab J Nephrol Transplant. 2012; 5 (3): 145-7.

[20] Collins AJ, Foley RN, Chavers B, Gilbertson D, Herzog C, Johansen K, Kasiske B, Kutner N, Liu J, St Peter W, Guo H, Gustafson S, Heubner B, Lamb K, Li S, Li S, Peng Y, Qiu Y, Roberts T, Skeans M, Snyder J, Solid C, Thompson B, Wang C, Weinhandl E, Zaun D, Arko C, Chen SC, Daniels F, Ebben J, Frazier E, Hanzlik C, Johnson R, Sheets D, Wang X, Forrest B, Constantini E, Everson S, Eggers P, Agodoa L. United States Renal Data System, USRDS 2011. Annual Data Report: Atlas of chronic kidney disease \& end-stage renal disease in the United States. AJKD 2012; 59 (1): A7.

[21] Stel VS, van de Luijtgaarden MW, Wanner C and Jager KJ; on Behalf of the European Renal Registry Investigators. The 2008 ERA-EDTA registry annual report-a précis. NDT Plus 2011; 4 (1): 1-13.

[22] Elsharif ME and Elsharif EG: Causes of End-Stage Renal Disease in Sudan: A Single-Center Experience. Saudi J Kidney Dis Transpl 2011; 22 (2): 373-6.

[23] United States Renal Data System public health surveillance of chronic kidney disease and end-stage renal diseaseKidney Int Suppl. 2015; 5 (1): 2-7.

[24] National Kidney Foundation, 2015: www.kidney.org

[25] Ahmed HA, Yassinea YS, Tawafea AR and Ebazaway MM. Epidemiological study of patients on regular haemodialysis at the Kafer El-Shakh Governorate, Egypt. Menoufia Med J 2015; 28 (2): 267-71.

[26] Abdelaali B, Omar M, Taoufik D, Samir A, Saad M and Benyahia M: Hepatitis C Viral Prevalence and Seroconversion in Moroccan Hemodialysis Units: Eight Year Follow Up. J Med Diagn Meth 2013; 2 (5): 2-5.

[27] Frank C, Mohamed MK, Strickland GT, Lavanchy D, Arthur RR, Magder LS, El Khoby T, Abdel-Wahab Y, Aly Ohn ES, Anwar W and Sallam I: The role of parenteral antischistosomal therapy in the spread of hepatitis $\mathrm{C}$ virus in Egypt. Lancet. 2000;11; 355 (9207): 887-91.

[28] Alashek WA, McIntyre CW and Taal MW: Hepatitis B and C infection in haemodialysis in Libya: prevalence, incidence and risk factors. BMC Infectious Diseases 2012, 12:265.

[29] Saxena AK and Panhotra BR: The vulnerability of middle aged and elderly patients to hepatitis $\mathrm{C}$ virus infection in a high-prevalence hospital-based hemodialysis setting. J Am Geriatr Soc. 2004; 52 (2): 242-6.

[30] Ayman KARKAR: Hepatitis $\mathrm{C}$ in dialysis units: The Saudi Experience. Hemodialysis International 2007; 11 (3): 354-67.

[31] Fissell RB, Bragg-Gresham JL, Woods JD, Jadoul M, Gillespie B,Hedderwick SA, Rayner HC, Greenwood RN, Akiba T and Young EW: Patterns of hepatitis C prevalence and seroconversion in hemodialysis units from three continents: the DOPPS. Kidney Int 2004; 65 (6): 2335-42. 
[32] Soliman AR, AbdElaziz MM and El lawindi MI: Evaluation of an Isolation Program of Hepatitis C Virus Infected Hemodialysis Patients in Some Hemodialysis Centers in Egypt. ISRN Nephrology 2013; Article ID 395467: 1-5.

[33] O'Brien SF, Yi QL, Fan W, Scalia V, Kleinman SH and Vamvakas EC: Current incidence and estimated residual risk of transfusion-transmitted infections in donations made to Canadian Blood Services," Transfusion 2007; 47 (2): 316-25.

[34] Kidney Disease: Improving Global Outcomes (KDIGO). KDIGO clinical practice guidelines for the prevention, diagnosis, evaluation, and treatment of hepatitis $\mathrm{C}$ in chronic kidney disease. Kidney Int 2008; 73 (109): 1-99.
[35] Saxena AK, Panhotra BR, Sundaram DS, Naguib M, Venkateshappa CK, Uzzaman W and MulhimKA: Impact of dedicated space, dialysis equipment, and nursing staff on the transmission of hepatitis $\mathrm{C}$ virus in a hemodialysis unit of the Middle East. Am J Infect Control. 2003; 31 (1): 26-33.

[36] Gallego E, López A, Pérez J, Llamas F, Lorenzo I, López E, Illescas ML, Andrés E, Olivas E, Gómez-Roldan C.: Effect of isolation measures on the incidence and prevalence of hepatitis $\mathrm{C}$ virus infection in hemodialysis. Nephron ClinPract. 2006; 104 (1): 1-6. 